\title{
Evaluation of mineral element content of beetroot during the different stages of the growing season
}

\author{
MÁRIA TAKÁCSNÉ HÁJOS - TÍMEA RUBÓCZKI \\ University of Debrecen, Faculty of Agricultural and Food Sciences and \\ Environmental Management, Institute of Horticultural Science, \\ Debrecen, Hungary \\ hajos@agr.unideb.hu
}

\begin{abstract}
Summary
In modern nutrition, bioactive materials of different vegetables are especially important to be researched. The experiment was carried out on March 30, 2016 (sowing date). Mineral element content (B, Ca, Cu, Fe, K, Mg, Na, P, S, Zn) was evaluated on the $60^{\text {th }}, 85^{\text {th }}$ and the $105^{\text {th }}$ day of the vegetation period. The data are presented as the mean of five varieties which can give the real state of these parameters of beetroot grown on lowland chernozem soil.

In the young beetroot leaves (60 days) the mineral element content was higher than in the older ones ( 85 days). The calcium and magnesium content of the leaves was much more favourable (10 times higher) than in the root. The potassium content of leaves has reached the amount of $5000 \mathrm{mg} \mathrm{kg}^{-1}$, but at the same time more than $3000 \mathrm{mg} \mathrm{kg}^{-1}$ was detected in the improved root. This value is favourable for the potassium supply of the human organism.

The sulphur content $\left(1300 \mathrm{mg} \mathrm{kg}^{-1}\right)$ of the leaves was the highest on the $85^{\text {th }}$ day of vegetation period. Similar tendency was detected for boron content $(2.45$ $\mathrm{mg} \mathrm{kg}-1)$, while for iron content it was higher $\left(28.23 \mathrm{mg} \mathrm{kg}^{-1}\right)$ in the younger leaves (60 days).

Finally, it can be concluded that the increased element content of beetroot leaves will be a favourable source of mineral element supply of the human organism.
\end{abstract}

Keywords: beetroot leaf, beetroot root, mineral element content, spring time cultivation

\section{Introduction}

The beetroot (Beta vulgaris ssp. esculenta var. rubra L.) belongs to the Chenopodiaceae family. Its progenitor the wild form of Beta vulgaris L. var. maritima which is originated from the Mediterranean Sea region.

Varieties with short vegetation have small or middle leaf lengths which can promote the intensive root development. The size of foliage has connection with the possibility of mechanical harvest. Between the varieties there are important differences in the lengths of leaf petiole and its colour content. Small leaf varieties have thinner petiole and deep 
purple colour, while the long leaf varieties have orange petiole with purple stripes.

Several researchers suppose connection between the petiole and root colour intensity. In our earlier experiment we have detected, that the short season varieties had smaller leaves and faster root improvement (Takácsné Hájos et al., 1999).

The beetroot has very good colour intensity, which is determined by the ratio of red betacyanins and yellow betaxanthine content. It is influenced by genetic (variety) and environmental (growing circumstance) factors as well (Takácsné Hájos, 1999).

This vegetable contains high amount of phenolic components, which can work as antioxidant and take part in prevention against tumour and cardio vascular disease (Yao et al., 2004). Its moderate and long-time consumption can prevent several diseases (Nyirády et al., 2010).

The carotenoids and ascorbic acid content of beetroot can increase the antioxidant capacity (Wootton-Beard and Ryan, 2011).

Compering with other vegetables, beetroot has rather high folic acid content in raw material and processed product as well. The daily folic acid need can be supplied by $200 \mathrm{~g}$ beetroot consumption. This favourable effect is connected with dark green leaves and higher betanine content.

According to Hoppner and his co-workers (1972), there are high differences between the varieties in this parameter (3.8-15.2 $\mathrm{\mu g}$ per $\mathrm{g}$ solids content). The folic acid or folate (vitamin $\mathrm{B}_{9}$ ) has neuroprotective effect and favourable against heart attack and several tumour disease (Maison, 1994).

The oxalate content of table beet leaves is not too high and it can be eliminated by cooking or fermentation (Ninfali and Angelino, 2013).

The high nitrate content can be unfavourable; however, Presley et al. (2011) proved that till $1000 \mathrm{mg} \mathrm{kg}^{-1}$ nitrate content can cause favourable effect to decrease the progress of dementia. Furthermore, it plays an important role (with folic acid) in the protection against Alzheimer disease. Moreover, Bryan and Pierini (2013) stated that it can increase the efficiency among athletes as well.

The root of beetroot can store rather high amount mineral element. The core of the root has higher mineral element than the inner part, so the beetroot should be peeled thinly to avoid the loss of bioactive compounds (Takács-Hájos, 2011).

Researchers have found $336 \mathrm{mg}$ per $100 \mathrm{~g}$ potassium content and 25 mg per $100 \mathrm{~g}$ magnesium content in the root on meadow silt soil (TakácsHájos, 2009). 
The insufficient mineral and trace element supply has a relationship with the development of several diseases. Beetroot has rather high macro and micro element content.

The physiological importance of ion ratio $\left(\mathrm{Ca}^{2+}+\mathrm{Na}^{+}\right) /\left(\mathrm{Mg}^{2+}+\mathrm{K}^{2+}\right)$ is optimal in the human organism when it is about 1.0. Experiments have proved that the $\mathrm{Mg}, \mathrm{Ca}, \mathrm{Mn}, \mathrm{Fe}, \mathrm{Cu}$ and $\mathrm{Zn}$ content of the lamina is multiple of the values measured in the petiole. The ion ratio was lower in the petiole in all varieties which were tested. According to this result the consumption of petiole has as much importance as the lamina in the fresh consumption (Takacs-Hajos et al., 2009). This seems to explain the reason why beetroot leaves were used for healing in ancient times.

The aim of the experiment was to evaluate the mineral element content during the vegetation period $\left(60^{\text {th }}, 85^{\text {th }}\right.$ and $105^{\text {th }}$ day), and to suggest the proper time of harvest in case of fresh consumption.

\section{Material and methods}

The experiment was carried out at the University of Debrecen, Farm and Regional Research Institute in its Botanical and Exhibition Garden. In order to have representative results about the species, five varieties were observed. The sowing date was 30 of March, 2016. The space between rows was $40 \mathrm{~cm}$, the size of parcels were $5 \mathrm{~m} \times 0.8 \mathrm{~m}$ with 2-2 rows on it.

The genotypes were grown which are propagated by seed (clusters holding from 3 to 5 seeds). Therefore, it is necessary to thin the beets when they are young ( 2 to 4 leaves). Besides the thinning, weeding and plant protection was done during the growing period.

The daily temperature (Figure 1) range has reached the $20{ }^{\circ} \mathrm{C}$ at the beginning of the vegetation period. Because of the tolerance to cold, no damage was found in the development of beetroot.

According to data, in the second half of May the daily maximum temperature rarely was decreased to $25{ }^{\circ} \mathrm{C}$ which helped the synthesis of bioactive compounds.

During the vegetation, the natural precipitation was not uniformly distributed. In order to complete the water need of plants, drop irrigation was applied with $20-25 \mathrm{~mm}$ amount of water occasionally.

The experiment was performed on lowland chernozem soil type, which data is presented on Table 1. As the data shows, the plasticity, the mineral element content and the $\mathrm{pH}$ of the soil is good for growing beetroot.

The sampling was done 3 times during the vegetation (30 of May, 23 of June and 13 of July), which were at the stage of 60, 85 and 105 days of vegetation. For the sampling, 10 representative plants were chosen from each variety to have an average sample. 
Figure 1. Minimum and maximum temperature values during the vegetation period (Debrecen, 2016)

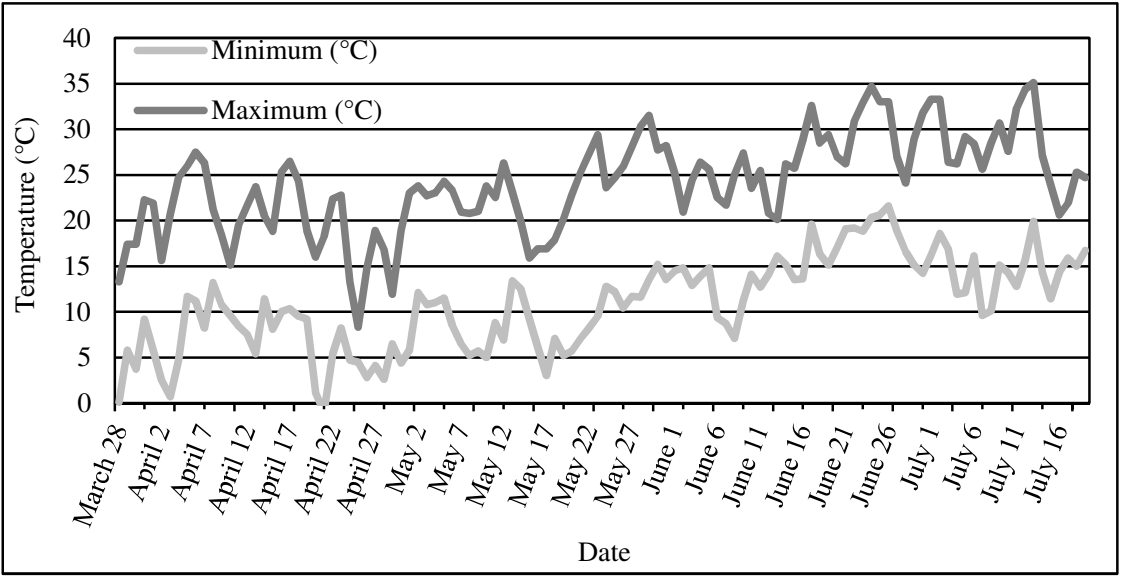

Table 1. The soil analysis of experimental field (Debrecen, 2016)

\begin{tabular}{lc}
\hline \multicolumn{1}{c}{ Analysed parameter (unit of measurement) } & Amount \\
\hline $\mathrm{pH}(\mathrm{KCL})$ & 6.83 \\
Plasticity index of Arany $\mathrm{K}_{\mathrm{A}}$ & 38 \\
Total water soluble salt $\%(\mathrm{w} / \mathrm{w})$ & 0.04 \\
$\mathrm{CaCO}_{3} \%(\mathrm{w} / \mathrm{w})$ & 0.99 \\
Humus\% (w/w) & 2.91 \\
AL-soluble $\mathrm{P}_{2} \mathrm{O}_{5}\left(\mathrm{mg} \mathrm{kg}^{-1}\right)$ & 481 \\
AL-soluble $\mathrm{K}_{2} \mathrm{O}\left(\mathrm{mg} \mathrm{kg}^{-1}\right)$ & 309 \\
KCL-soluble $\mathrm{NO}_{3}^{-}+\mathrm{NO}_{2}^{-}-$Nitrogen $\left(\mathrm{mg} \mathrm{kg}^{-1}\right)$ & 2.16 \\
\hline
\end{tabular}

Regarding to measurements, they were performed at the Agricultural Laboratory Centre, University of Debrecen and were the following:

Total dry matter content (\%) by the standard of MSZ-08-1783-1:1983 chapter 2.

Mineral element content $\left(\mathrm{mg} \mathrm{kg}^{-1}\right)-\mathrm{B}, \mathrm{Ca}, \mathrm{Cu}, \mathrm{Fe}, \mathrm{K}, \mathrm{Mg}, \mathrm{Na}, \mathrm{P}, \mathrm{S} \mathrm{Zn}$ with ICP-AES, the preparation of the samples was with cremation at 550 ${ }^{\circ} \mathrm{C}$ by the standard of MSZ-08-1783:1983

The main object of this work was to evaluate and to compare the bioactive compounds as dry matter content and total solids content of the beet in the root and in the leaf when they are consumable. 


\section{Results and discussion}

Total dry matter content

One important quality parameters of vegetables is the total dry matter content. In the different part of the beetroot plant we have found great differences in it (Figure 2).

Figure 2. Total dry matter content (\%) of beetroot in leaf and in root at different growing stages (Debrecen, 2016)

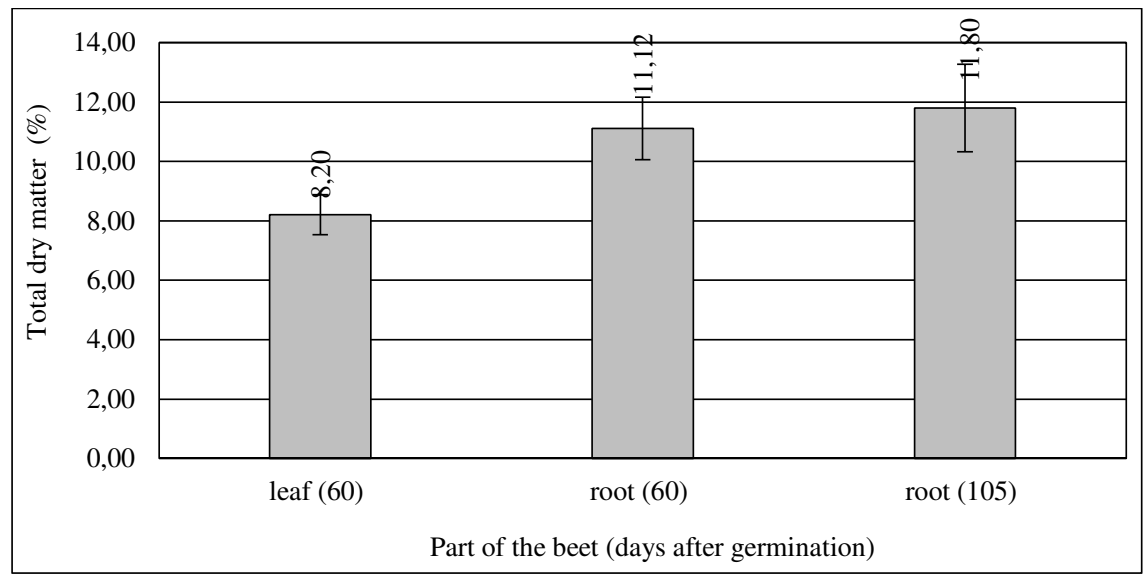

In the leaves its content is about $8 \%$ comparing to the same improved root, where this amount is higher $(11.12 \%)$. According to earlier experiment (Raczkó et al., 2015), this parameter was higher (16\%) by the second crop production where the sowing time was at the end of June.

We can state that the root of spring time production was fresher and younger than the one which was harvested in October.

\section{Mineral element content}

The potassium has one of the highest amount in the vegetables. It was proved in the case of beetroot as well by the analysis of potassium content which was the highest at the age of 85 days of the leaves (Figure 3).

Lower amounts were measured in the root not only for the potassium, but for the sodium as well. Similar result was found by Csikkel-Szolnoki et al. (2002). Beetroot at the age of 60 days has soft and consumable leaves. In this stage the potassium content was more than $4000 \mathrm{mg} \mathrm{kg}^{-1}$.

This is the main reason that the potassium intake of the human organism can be complemented with fresh beetroot leaves as component of green salad mixes. In the older leaves ( 85 days) the potassium content 
is higher. However, the fiber content of leaf stalk is higher. The sodium content is rather low in the beetroot which is even less amount in the root.

More attention has to be paid for the regular supply of calcium and magnesium which importance is rather high in the human organism. For these elements 8-10 times higher amount was detected in the leaves than in the root (Figure 4).

Figure 3. Kand Na content of beetroot in leaf and in root at different growing stages (Debrecen, 2016)

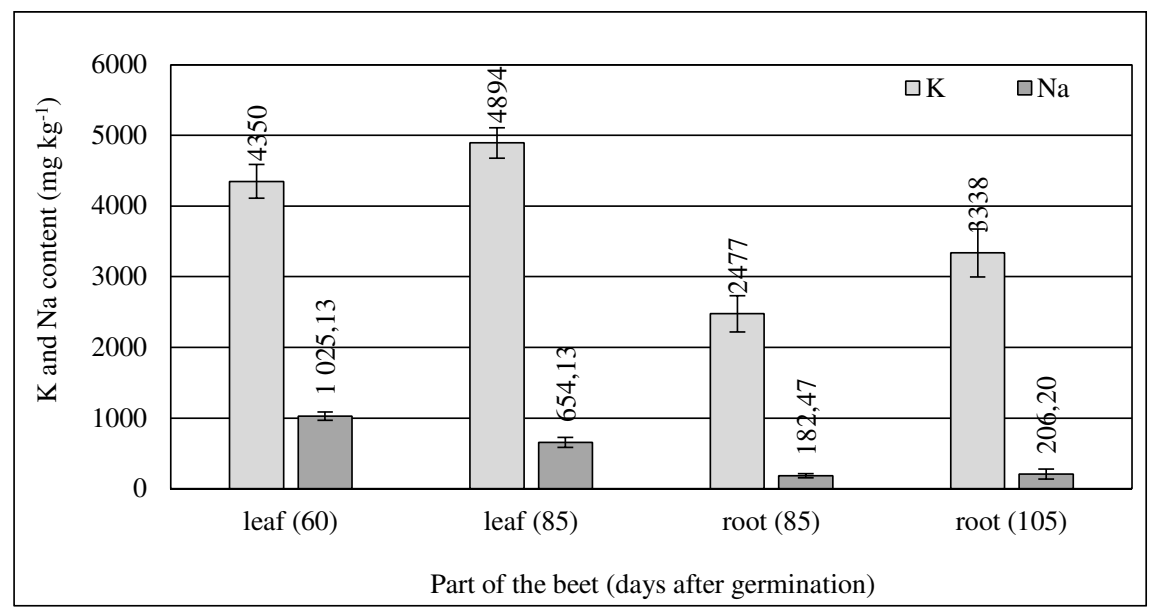

Figure 4. Ca and $\mathrm{Mg}$ content of beetroot in leaf and in root at different growing stages (Debrecen, 2016)

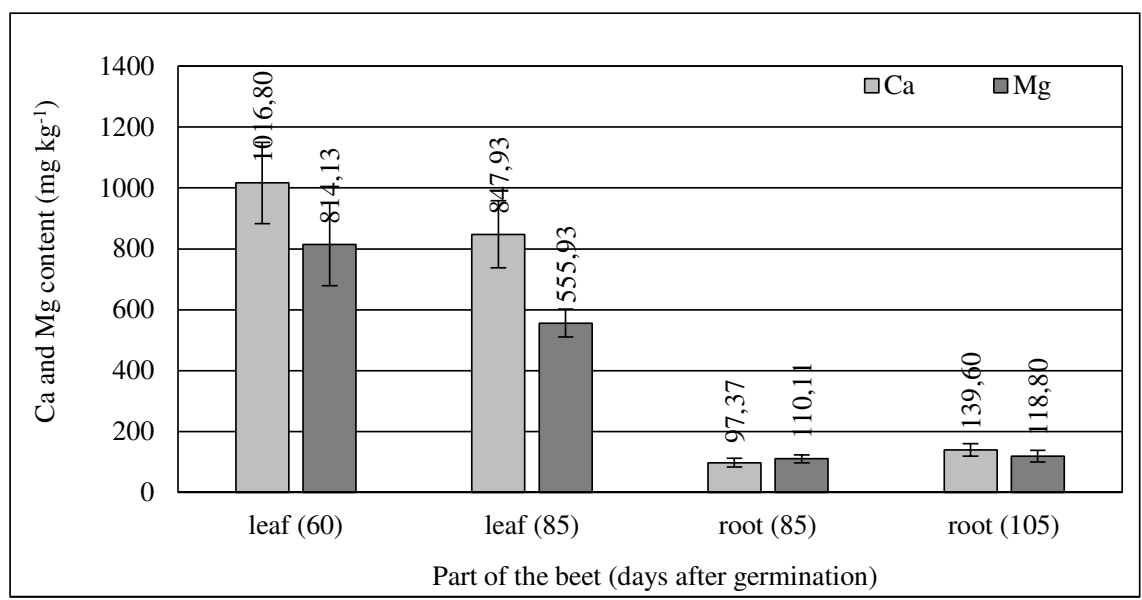


The younger leaves (60 days) had higher calcium and magnesium content than the older ones ( 85 days).

The evaluation of mineral element content is influenced by the soil element content and the growing method as well. Earlier experiments (Takácsné Hájos and Szőllősiné Varga, 2004) have proved that the beetroot can accumulate higher calcium and magnesium content (for $\mathrm{Ca}$ $1820 \mathrm{mg} \mathrm{kg}^{-1}$ and for $\mathrm{Mg} 1480 \mathrm{mg} \mathrm{kg}^{-1}$ ) by second crop production on silty loam soil. This study has proved the negative effect on the calcium and magnesium accumulation by spring time sowing and drip irrigation.

The calcium, magnesium, potassium and sodium have great role in the ion ratio $-\left(\mathrm{Ca}^{2+}+\mathrm{Na}^{+}\right) /\left(\mathrm{Mg}^{2+}+\mathrm{K}^{+}\right)-$in the human organism. The optimal value is 1.0, however, most of the cases it is between 2.0 and 2.5. Explanation can be found in higher sodium intake (salt consumption).

The vegetables, such as beetroot has an important role to have an optimal ion ratio in the human organism. This value as usual is lower than 1.0 in the vegetable species.

Similar tendency was detected in our experiment where the leaves and roots have very low ratio (Figure 5).

Figure 5. $\left(\mathrm{Ca}^{2+}+\mathrm{Na}^{+}\right) /\left(\mathrm{Mg}^{2+}+\mathrm{K}^{+}\right)$ion ratio of beetroot in leaf and in root at different growing stages (Debrecen, 2016)

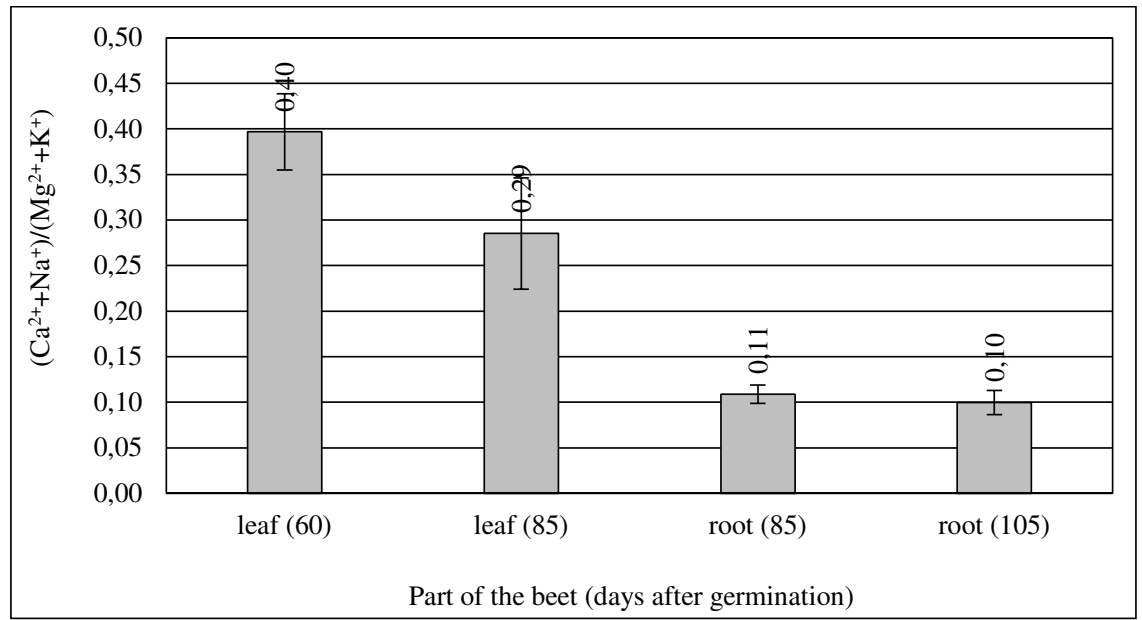

Finally, we can summarize that the increased potassium, magnesium content and rather high calcium supply can ensure favourable nutrition physiological effect.

The sulphur is the $6^{\text {th }}$ important element in the physiology which role lies in the synthesis of protein and several vitamins (as $B_{1}$ vitamin) and it 
takes part in different redox systems. The highest sulphur content was detected in the leaves at the age of 85 days of vegetation period (Figure 6).

The same element content was rather low in the root. Significant differences were not found in the phosphorus content between the leaf and the root at the different growing stages.

Data of $\mathrm{Cu}, \mathrm{Fe}$ and $\mathrm{Zn}$ content has shown on Figure 7.

Figure 6. $P$ and $S$ content of beetroot in leaf and in root at different growing stages (Debrecen, 2016)

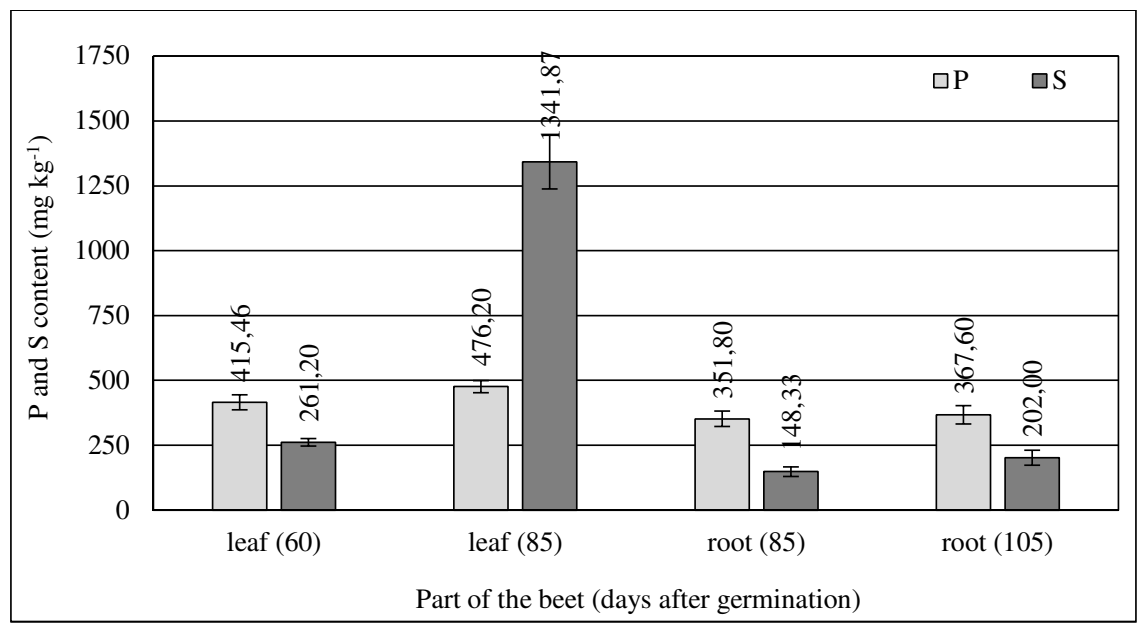

Figure 7. Cu, Fe and $\mathrm{Zn}$ content of beetroot in leaf and in root at different growing stages (Debrecen, 2016)

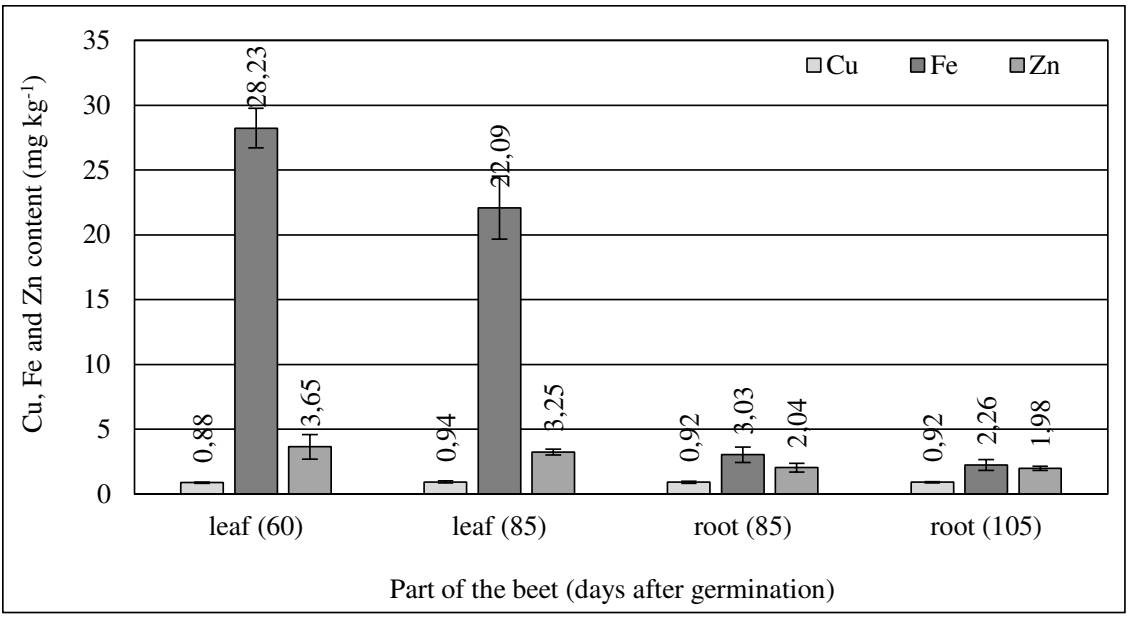


Among the evaluated elements the iron has exceeded with high concentration in the leaves. Besides, the 60 days old leaves have shown the highest amount $\left(28.23 \mathrm{mg} \mathrm{kg}^{-1}\right)$ in the mean of varieties. The values of the iron content in the root was about one-tenth of the values measured in the leaves.

However, it is well known that in the human organism the iron absorption is much lower from the vegetables which can be explained with higher organic acid content.

The zinc has important role in the enzymatic activity, insulin synthesis and carbohydrate metabolism. In our experiment the zinc content was higher in the leaves than in the root. These data are in synchronous with earlier measurements (Csikkel-Szolnoki et al., 2002). The copper content was nearly similar in the different part of beetroot. The boron is an essential microelement which is important in the nutrition element uptake, transport of carbohydrate and other assimilate. This element is accumulated meanly in the vegetative parts of the plant.

Its content is higher in the dicotyledon plants than in the monocotyledon ones (Loch and Nosticzius, 2004). In the human physiology it has an important part in the vitamin D activation. Two times higher boron content was detected in the leaves than in the root in our experiment (Figure 8). The older plant parts ( 85 days old leaf and 105 days old root) showed higher boron content.

Figure 8. B content of beetroot at the different stages of growing period (Debrecen, 2016)

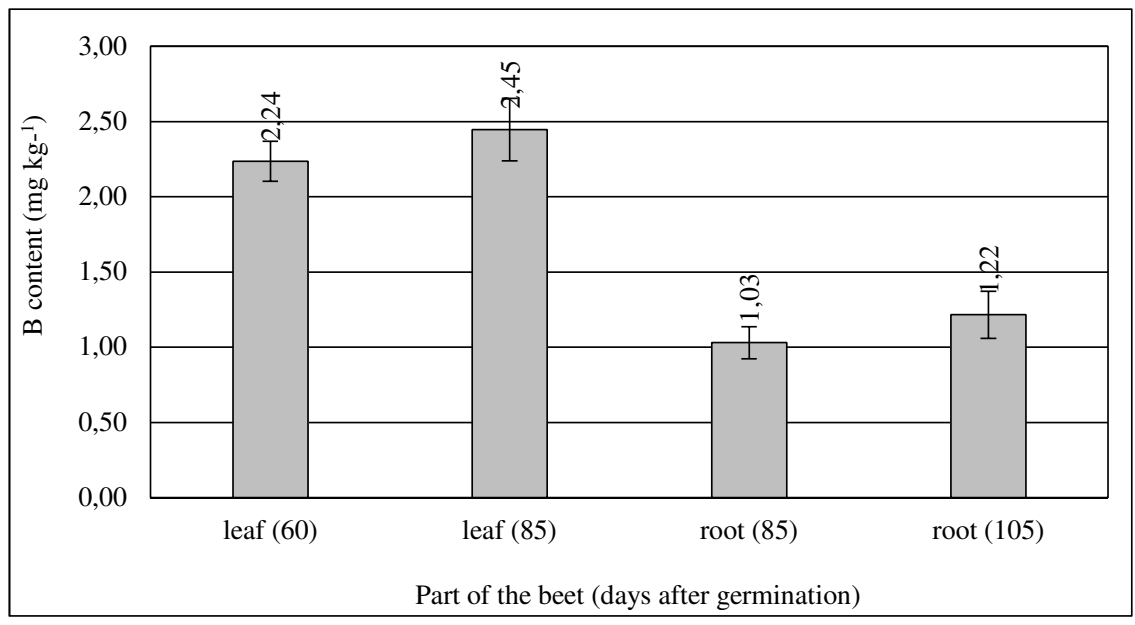




\section{Conclusion}

The experiment was carried out on lowland chernozem soil, with spring time sowing date (30 March of 2016). The data are presented in the mean of five varieties. The aim was to evaluate the mineral element content during the vegetation period $\left(60^{\text {th }}, 85^{\text {th }}\right.$ and $105^{\text {th }}$ day) to determine the proper time of harvest when the bioactive compounds are available in high amounts for fresh consumption.

The measurements have proved that the 60 days old leaves have higher calcium and magnesium content than the older ones. The leaves have shown more favourable mineral element content compare to the root for nearly every parameter. The ion ratio was between 0.1 and 0.4 for the leaves and the roots which is recommended for human consumption. Among the microelements the iron was found in the highest amount (25$30 \mathrm{mg} \mathrm{kg}^{-1}$ ) in the leaves (60 days).

Extremely high sulphur content was detected on the 85 days of the vegetation period in the leaves. The publication of boron content of beetroot is not satisfactory. The boron supply of the leaves $(2.3-2.5 \mathrm{mg}$ $\mathrm{kg}^{-1}$ ) were nearly two times higher than in the root in our circumstances. The elder leaves ( 85 days) have shown the highest boron content.

\section{Acknowledgments}

This study was supported by the EFOP-3.6.3-VEKOP-16-2017-00008.

\section{References}

Bryan, N. S.-Pierini, C. (2013): Beet the Odds. Harness the power of beets to radically transform your health. Neogenis. USA. 46.

Csikkel-Szolnoki, A.-Takács-Hájos, M.-Kiss, A. S. (2002): Trace element content in table beet roots depending on varieties. The $10^{\text {th }}$ International Trace Element Conference. 4-6 July 2002. 10.

Hoppner, K.-Lambi, B.-Perrin, D. E. (1972): The free and total folate activity in foods available on the Canadian market. J. Inst. Can. Sci. Technol. Aliment. 5: 60-66.

Loch J.-Nosticzius Á. (2004): Agrokémia és növényvédelmi kémia. Mezőgazda Kiadó. Budapest. 346.

Maison, J. B. (1994): Folate and colonic carciogenesis: search for a mechanistic understanding. J. Nutr. Biochem. 5: 170-175.

Ninfali, P.-Angelino, D. (2013): Nutritional and functional potential of Beta vulgaris cicla and rubra. Fitoterapia. 89: 188-199. 
Nyirádi, P.-Sárdi, É.-Bekő, G.-Szücs, M.-Horváth, A.-Székely, E.-Szentmihályi, K.Romics, I.-Blázovics, A. (2010): Effects of bioactive molecules of Beta vulgaris L. ssp. esculenta var. rubra on metastatic prostate cancer. Orvosi Hetilap. 37: 1495-1503.

Presley, T. D.-Morgan, A. R.-Bechtold, E.-Clodfelter, W.-Dove, R. W.-Jennings, J. M.Kraft, R. A.-King, S. B.-Laurienti, P. J.-Rejeski, W. J.-Burdette, J. H.-Kim-Shapiro, D. B.-Miller, G. D. (2011): Acute effect of a high nitrate diet on brain perfusion in older adults. Nitric Oxide. 24. 1: 34-42.

Raczkó V.-Rubóczki T.-Borbélyné Varga M.-Takácsné Hájos M. (2015): Cékla (Beta vulgaris L. ssp. esculenta Gurke var. rubra L.) beltartalmi paramétereinek változása tárolás hatására. Agrártudományi Közlemények. 63: 113-119.

Takácsné Hájos, M. (1999): Colour components of different table beet varieties. Intern. J. of Hort. Sci. 5. 3-4: 36-39.

Takácsné Hájos M. (2009): Cékla. [In: Hodossi S. et al. (szerk.) Zöldségtermesztés szabadföldön. Mezőgazda Kiadó. Budapest. 270-275.

Takácsné Hájos M. (2011): Cékla termesztése. [In: Kovács A. (szerk.) Gyökérzöldségek termesztése.] Mezőgazda Kiadó. Budapest. 87-107.

Takácsné Hájos, M.-Csikkel-Szolnoki, A.-Kiss, A. S. (1999): Mineral content of table beet roots as depending on varieties. Magnesium Research. 12: 326-327.

Takacs-Hajos, M.-Kastori, R.-Pucarevic, M.-Zeremski Skoric, T. (2009): Microelement content of leaves of different table beet varieties (Beta vulgaris ssp. esculenta var. rubra) trace elements in the food chain. Vol. 3. Deficiency or Excess of Trace Elements in the Environment as a Risk of Health. 21-23 May 2009. 327-331.

Takácsné Hájos, M.-Szőllősiné Varga, I. (2004): Magnézium lombtrágyázás hatása a cékla (Beta vulgaris ssp. esculenta var. rubra) morfológiai és beltartalmi tulajdonságaira, valamint azok összefüggéseire. Agrártudományi Közlemények. 14: 67-72.

Wootton-Beard, P. C.-Ryan, L. (2011): A beetroot juice shot is a significant and convenient source of bioaccessible antioxidants. Journal of Functional Foods. 3: 329-334.

Yao, L. H.-Jiang, Y. M.-Shi, J.-Tomas-Barberan, F. A.-Datta, N.-Singanusong, R.Chen, S. S. (2004): Flavonoids in food and their health benefits. Plant Foods for Human Nutrition (Formerly Qualitas Plantarum). 59: 3. 